\title{
Using Experience and Supplementation to Increase Juniper Consumption by Three Different Breeds of Sheep
}

\author{
Jess R. Anderson, ${ }^{1}$ Cody B. Scott, ${ }^{2}$ Charles A. Taylor, Jr., ${ }^{3}$ Corey J. Owens, ${ }^{4}$ James R. Jackson, ${ }^{1}$ \\ Diana K. Steele, ${ }^{1}$ and Richard Brantley ${ }^{5}$
}

Authors are ${ }^{1}$ Former Graduate Assistants, ${ }^{2}$ Professor, and ${ }^{4}$ Research Associate, Department of Agriculture, Angelo State University, San Angelo, TX 76909, USA; ${ }^{3}$ Supervisor, Texas AgriLife Experiment Station, Sonora, TX 76950, USA; and ${ }^{5}$ Director of Surface Interests, University Lands, Midland, TX 79705, USA.

\begin{abstract}
In the southwestern United States, redberry (Juniperus pinchotii Sudw.) and ashe (Juniperus ashei Buchholz) juniper are two invasive species that dominate some rangelands. Goats will consume up to $30 \%$ of their diet in juniper, but it is unknown if sheep will accept juniper to the same extent. The objectives of this study were to determine if sheep can be conditioned to consume juniper and to compare intake among different breeds. Rambouillet $(n=10)$, Suffolk $(n=10)$, and Dorper-cross $(n=10)$ lambs were randomly placed in individual pens for $31 \mathrm{~d}$. A basal diet of alfalfa pellets $(2.5 \%$ body weight [BW]) and juniper were fed. Juniper was fed each morning from 0800 to 0830 hours. The basal diet was fed for the remainder of the day. Intake of each was measured daily. Following the first $17 \mathrm{~d}$, the basal diet was reduced to $2 \% \mathrm{BW}$ for $7 \mathrm{~d}$ and then reduced to $1.5 \% \mathrm{BW}$ for the final $7 \mathrm{~d}$. Serum aspartate transaminase (AST), gamma glutamyltransferase (GGT), blood urea nitrogen (BUN), creatinine, and bilirubin levels, and live body weight were measured to assess any adverse physiological effects from juniper consumption. In a second trial, lambs were again fed alfalfa $(2.5 \% \mathrm{BW})$ and juniper. One half of the lambs were also fed a $36 \%$ protein supplement to determine if supplementation with protein sources that escape rumen degradation would improve juniper consumption. Lambs received alfalfa, juniper, and protein supplement for $22 \mathrm{~d}$ with intake of each recorded daily. Intake of juniper was similar $(P>0.05)$ among breeds of sheep. Lambs readily consumed juniper and increased $(P<0.05)$ intake of juniper as the amount of alfalfa fed was reduced. Weight change was also similar among treatments. Protein supplementation did not improve juniper consumption. We contend that sheep will consume a diet consisting of $24 \%$ juniper without experiencing any adverse effects.
\end{abstract}

Key Words: conditioning, Dorper, intake, Juniperus, Rambouillet, Suffolk

\section{INTRODUCTION}

The rapid expansion of two invasive shrubs, redberry (Juniperus pinchotii Sudw.) and ashe (Juniperus ashei Buchholz) juniper are a major concern for many in the southwestern United States (Ansley et al. 1995; Smeins and Fuhlendorf 1997). The expansion of juniper results in a loss of plant diversity, reduced herbaceous production, and decreased water yield (Dye et al. 1995; Wilcox 2002; Wilcox et al. 2005). Livestock and wildlife typically avoid consuming both species of juniper because of monoterpenoids that cause aversive postingestive feedback and the formation of conditioned food aversions (Riddle et al. 1996; Pritz et al. 1997). Control options are available but are cost-prohibitive in most situations (Johnson et al. 1999). For example, chemical treatment with herbicides that contain Picloram can be effective but is costly and only effective on small junipers. Prescribed burning effectively controls ashe juniper, but redberry juniper resprouts after top-kill from fire (Wink and Wright 1973; Steuter and

Research reported herein was supported by University Lands and the Angelo State University Management, Instruction, and Research Center.

Correspondence: Cody Scott, Box \#10888 ASU Station, San Angelo, TX 76909, USA. Email: Cody.Scott@angelo.edu

Manuscript received 11 January 2012; manuscript accepted 15 September 2012.

(c) 2013 The Society for Range Management
Britton 1983). Because of the limitations of other control measures, alternative control options are needed.

Goats will consume juniper on pasture after conditioning a preference for the plant in individual pens (Dietz et al. 2010). Goats increase intake of juniper after feeding the plant $14 \mathrm{~d}$ after weaning (Bisson et al. 2001; Ellis et al. 2005; Dunson et al. 2007). This protocol has relied on initially feeding $50 \mathrm{~g}$ of juniper for $30 \mathrm{~min}$ each day. The amount of juniper is increased by $25 \mathrm{~g}$ as goats consume all the juniper offered. By the end of the 14-d feeding trials, juniper typically accounts for $30 \%$ of their diet. Feeding more juniper initially or increasing the amount of juniper offered too quickly results in the formation of conditioned food aversions and avoidance of juniper (Dietz et al. 2010).

Some livestock producers stock sheep rather than goats or might stock both species on the same rangelands. At this time, there is little available evidence regarding juniper acceptance by sheep. In addition, hair sheep breeds such as the Dorper are gaining popularity across the southwestern United States because of their reduced susceptibility to internal parasites, because they do not require annual shearing, and because they might browse more than other breeds of sheep (M. W. Salisbury et al., unpublished data). Unfortunately, it is not known if conditioning (i.e., feeding juniper at weaning for $14 \mathrm{~d}$ ) could be used to increase acceptance of the plant by sheep. The purpose of this project was to determine if sheep can be conditioned to consume juniper and if there were any differences among three 
common breeds' acceptance of juniper. This project also assessed the effect of the basal diet restriction and protein supplementation on juniper consumption by sheep.

\section{MATERIALS AND METHODS}

This study was conducted at Angelo State University's Management, Instruction, and Research Center in San Angelo, Texas (lat $31.38^{\circ} \mathrm{N}$, long $100.5^{\circ} \mathrm{W}$ ). To determine if breeds differ in their willingness to consume juniper, 30 freshly weaned 7-mo-old ewe lambs with an average weight of $31.8 \pm 0.9 \mathrm{~kg}$ were offered juniper daily after weaning. All lambs were dewormed with Ivermectin and vaccinated for Enterotoxemia at weaning. The research protocol was approved by the Angelo State University Institutional Animal Care and Use Committee.

Treatments consisted of three breeds of sheep (Rambouillet, Suffolk, and Dorper cross) with each breed consisting of 10 ewe lambs. Prior to initiation of the study, recently weaned lambs were weighed and randomly placed in individual pens (1 $\mathrm{m} \times 1.5 \mathrm{~m})$. All animals were provided fresh water and trace mineral blocks ad libitum throughout the study, and excreta was removed weekly. In addition, all lambs were offered juniper daily. Fresh redberry juniper was collected at the Texas AgriLife Research Station, Sonora, Texas (lat $30.58^{\circ} \mathrm{N}$, long $\left.100.65^{\circ} \mathrm{W}\right)$. Leaves were hand-stripped from randomly selected trees and stored at $4^{\circ} \mathrm{C}$ until feeding (Utsumi et al. 2006). Immediately prior to feeding, leaves were composited and hand-mixed to insure consistency.

All sheep were given a 7-d adjustment period and fed alfalfa pellets $(2.5 \%$ body weight $[\mathrm{BW}])$ alone in order to meet nutritional requirements (National Research Council [NRC] 2007). Immediately following the adjustment period, lambs were offered $50 \mathrm{~g}$ of redberry juniper daily for $17 \mathrm{~d}$ along with alfalfa pellets $(2.5 \% \mathrm{BW})$. Juniper was offered from 0800 to 0830 hours each day. The amount of juniper offered was initially limited to $50 \mathrm{~g}$ because overingestion can lead to the formation of condition food aversions. Other studies have illustrated that aversions to juniper can be avoided if the amount of juniper offered is increased slowly over a $14-\mathrm{d}$ feeding trial (Dunson et al. 2007; Dietz et al. 2010). Thereafter, alfalfa was fed from 0900 until 0800 hours the following day. The amount of juniper and alfalfa consumed was recorded daily during each day of the study for individual lambs. If the entire amount of juniper offered was consumed on any given day, the amount of juniper fed was increased until refusals were noted.

On days 18 through 24, each animal's basal diet of alfalfa pellets was decreased to $2 \% \mathrm{BW}$. On days 25 through 31 , the basal diet was decreased to $1.5 \% \mathrm{BW}$ with juniper intake monitored throughout both periods. Intake of juniper was measured daily and compared between feeding periods ( $2.5 \mathrm{vs}$. 2.0 vs. $1.5 \mathrm{~g} \cdot \mathrm{kg}^{-1} \mathrm{BW}$ ) and across the entire feeding trial. Immediately following day 31, all animals were weighed. Previous live weights recorded were compared to final live weights to identify weight gain/loss.

Serum samples that can indicate soft tissue damage from toxicosis (Cornelius 1989) were taken on day 1 (initial), day 18, day 25, and day 31 (ending). These collection dates coincided with reductions in the amount of the basal ration offered each day. Blood samples were taken via jugular venipuncture. Thirty min after collection, samples were placed in a centrifuge $(3,000 \times \mathrm{g}$ for $20 \mathrm{~min})$ to separate the serum, and then stored in a freezer at $-80^{\circ} \mathrm{C}$. Following completion of the study, the samples were sent to the Texas Veterinary Medical Diagnostic Laboratory in College Station, Texas and analyzed for serum aspartate transaminase (AST), gamma glutamyltransferase (GGT), blood urea nitrogen (BUN), creatinine, and bilirubin.

A second trial was conducted the following summer because all lambs, regardless of breed, lost weight. The purpose of the trial was to determine if additional protein supplementation with protein sources consisting of amino acids that escape rumen degradation would 1) improve intake and 2) reduce weight loss. Twenty Rambouillet/Suffolk crossbred lambs were individually housed in $1 \times 1.5 \mathrm{~m}$ pens. All lambs received alfalfa pellets $(2.5 \% \mathrm{BW})$, ad libitum water and trace mineral blocks, and juniper daily for $22 \mathrm{~d}$. In addition, one-half of the lambs $(n=10)$ received additional protein supplementation $(36 \%$ crude protein $[\mathrm{CP}])$ to raise the daily protein intake to 200 $\mathrm{g} \cdot \mathrm{head}^{-1} \cdot \mathrm{d}^{-1}$. The supplement consisted of the following ingredients on an as fed basis: cottonseed meal (77.5\%), distiller's dried grains $(16.2 \%)$, cane molasses $(3.4 \%)$, rice bran $(2.5 \%)$, trace minerals $(0.02 \%)$, and vitamins $\mathrm{A}, \mathrm{D}$, and $\mathrm{E}$ $(0.3 \%)$. The protein supplement was offered from 0800 to 0830 hours followed by feeding juniper to all lambs from 0830 to 0900 hours. Alfalfa pellets were fed to all animals $(2.5 \%$ BW) for the remainder of the day for the first $14 \mathrm{~d}$. For the last $7 \mathrm{~d}$, the amount of alfalfa was increased to reach a protein intake of $200 \mathrm{~g} \cdot$ head $^{-1} \cdot \mathrm{d}^{-1}$ for the 10 lambs that did not receive the protein supplement. Redberry juniper was collected on the same site, using the same protocol as the previous trial. Juniper, alfalfa, and the protein supplement were fed separately, and intake of each was measured daily for $14 \mathrm{~d}$ using the same feeding protocol as the previous trial.

The study design for both trials was a completely randomized design with a model that included breed, day, period, and their interactions in the first trial. For the second trial, the model included treatment (supplement or no supplement), day, and their interactions. Weight change and serum metabolite data were compared among treatments, days, and feeding periods using the same model. Differences between treatment means (fixed effect) were assessed using repeated-measures analysis of variance. Individual lambs nested within treatments, and feeding periods served as replications (random effect). Day of observation served as a repeated measure. Means that differed were separated using Tukey's LSD when $P<0.05$. Data was analyzed using the statistical package JMP (SAS Institute Inc. 2007).

\section{RESULTS}

Intake of juniper and alfalfa was similar $(P>0.05)$ among breeds of sheep (i.e., treatments) throughout the study. All of the alfalfa was consumed each day. As for juniper intake, Dorpers consumed $3.8 \mathrm{~g} \cdot \mathrm{kg}^{-1} \mathrm{BW}$, Rambouillets consumed 2.8 $\mathrm{g} \cdot \mathrm{kg}^{-1} \mathrm{BW}$, and Suffolks consumed $3.7 \mathrm{~g} \cdot \mathrm{kg}^{-1} \mathrm{BW}$ $(\mathrm{SEM}=0.5)$. Intake of juniper increased $(P<0.05)$ across the $31 \mathrm{~d}$ of feeding when data were combined across three 
treatments (treatment $\times$ day interaction was not significant $P=0.99$; Fig. 1). All three breeds of sheep increased intake of juniper from Period 1 to Period 3. Sheep were initially hesitant to consume juniper; however, intake increased daily throughout the remainder of the trial. By the end of the trial, sheep were consuming over $6 \mathrm{~g} \cdot \mathrm{kg}^{-1}$ BW (24\% of total intake).

When juniper and alfalfa intake were compared across the three periods of the study, juniper intake increased. Similarly, alfalfa intake declined as the amount of alfalfa offered daily declined (Table 1). During the first $17 \mathrm{~d}$, juniper made up $4.6 \%$ of diet, $15.3 \%$ during days 18 to 24 , and $24.1 \%$ during days 25 to 31 (Table 1). Weight loss was similar $(P>0.05)$ among all breeds of sheep (Table 2). All breeds lost weight from the beginning to the end of the study. Rambouillets lost $6.6 \pm 1.6$ $\mathrm{kg}$, Suffolks lost $2.9 \pm 1.6 \mathrm{~kg}$, and Dorpers lost $3.7 \pm 1.6 \mathrm{~kg}$.

Serum metabolite levels were similar among breeds (Table 3 ) but differed $(P<0.05)$ by day of collection (Table 4$)$. Blood urea nitrogen levels were lower at the end of the study. Bilirubin levels were higher initially and declined as the study progressed. Creatinine levels increased as the study progressed. Serum aspartate transaminase (AST) levels were similar across all four collection periods. Gamma glutamyltransferase (GGT) levels also decreased as the study progressed. All serum metabolite levels remained within normal range for healthy individuals. In addition, most serum metabolite levels declined the longer sheep were fed juniper.

In the second trial, lambs consumed all of the protein supplement and alfalfa fed daily. Juniper intake increased across the $22 \mathrm{~d}$ of feeding regardless of protein supplementation (treatment effect, $P>0.05$; treatment $\times$ day, $P>0.05$; Fig. 2 ). Increasing the amount of alfalfa fed to lambs not receiving protein supplementation did not affect $(P>0.05)$ juniper intake during the last $7 \mathrm{~d}$ of the trial. Weight change was similar between treatments and $22 \mathrm{~d}$ of feeding (data not shown).

\section{DISCUSSION}

We suspected that breeds of sheep selected for different production characteristics (i.e., wool production vs. meat production) would differ in their ability to consume juniper. Our results suggest that intake of juniper by sheep was similar among the Rambouillet, Suffolk, and Dorper-cross breeds in this study. Conversely, juniper intake differs among breeds of

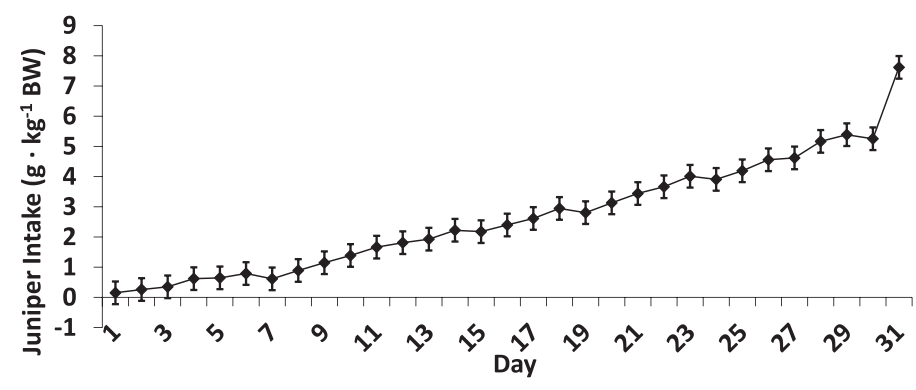

Figure 1. Intake $\left(\mathrm{g} \cdot \mathrm{kg}^{-1}\right.$ body weight $\left.[\mathrm{BW}]\right)$ of redberry juniper combined across the three breeds (treatment $\times$ day interaction did not differ) of sheep over $31 \mathrm{~d}$ of exposure in Trial 1 . Intake differed $(P<0.05)$ across days of feeding.
Table 1. Redberry juniper and alfalfa intake $\left(\mathrm{g} \cdot \mathrm{kg}^{-1}\right.$ body weight [BW] and percent of diet) across three periods in Trial 1. Intake was similar $(P>0.05)$ among treatments.

\begin{tabular}{|c|c|c|c|}
\hline \multirow[b]{2}{*}{ Forage $^{1}$} & \multicolumn{3}{|c|}{ Period } \\
\hline & 1 & 2 & 3 \\
\hline & \multicolumn{3}{|c|}{$\mathrm{g}_{\mathrm{L}} \mathrm{kg}^{-1} \mathrm{BW}$} \\
\hline Alfalfa $^{2}$ & $24.9 \mathrm{a}$ & $19.0 \mathrm{~b}$ & $15.3 \mathrm{c}$ \\
\hline Juniper & $1.3 \mathrm{c}$ & $3.4 \mathrm{~b}$ & $5.6 \mathrm{a}$ \\
\hline Total intake & $26.1 \mathrm{a}$ & $22.4 \mathrm{~b}$ & $20.6 c$ \\
\hline & & $-\%$ & \\
\hline Alfalfa (\% BW) & 2.5 & 2.0 & 1.5 \\
\hline Juniper (\% of diet) & $4.6 \mathrm{c}$ & $15.3 \mathrm{~b}$ & $24.1 \mathrm{a}$ \\
\hline
\end{tabular}

${ }^{1}$ Means within the same row with different superscripts differ $(P<0.05)$.

${ }^{2}$ The basal diet of alfalfa was decreased from 2.5\% BW (Period 1) to 2.0\% BW (Period 2) to $1.5 \%$ BW (Period 3).

Table 2. Weight change and standard error of mean (SEM) among three breeds of sheep in Trial 1. All animals lost weight; however, no statistical difference $(P>0.05)$ was found among the three breeds.

\begin{tabular}{|c|c|c|c|c|}
\hline \multirow[b]{2}{*}{ Breed } & \multicolumn{2}{|c|}{ Weight (kg) } & \multirow[b]{2}{*}{ SEM } & \multirow[b]{2}{*}{ Loss (kg) } \\
\hline & Initial & Final & & \\
\hline Rambouillet & 35.0 & 28.3 & 1.6 & 6.6 \\
\hline Suffolk & 29.7 & 26.8 & 1.6 & 2.9 \\
\hline Dorper-cross & 30.7 & 27.0 & 1.6 & 3.7 \\
\hline
\end{tabular}

goats. Spanish goats consume more juniper than Boer or Angora goats; and Boer goats consume more juniper than Angora goats (Pritz et al. 1997; C. A. Taylor, Jr., personal communication). In addition, there is evidence that goats can be genetically selected for juniper consumption (Campbell et al. 2007; Waldron et al. 2009). Even though Rambouillet, Suffolk, and Dorper-cross breeds have been selected for different production characteristics, genetic selection seems to have had little impact on their willingness to consume juniper.

All breeds of sheep used in this study increased intake of juniper during the course of exposure. These results are similar to the results with goats; feeding juniper in individual pens increased intake over time (Bisson et al. 2001; Ellis et al. 2005; Dunson et al. 2007). In addition, goats continue to consume

Table 3. Serum metabolite levels and standard error of mean (SEM) of each compared across Rambouillet, Suffolk, and Dorper-cross breeds when sheep were fed juniper for $31 \mathrm{~d}$ in Trial 1. Levels were similar $(P>0.05)$ among breeds.

\begin{tabular}{|c|c|c|c|c|c|}
\hline \multirow[b]{2}{*}{ Serum metabolite ${ }^{1}$} & \multicolumn{3}{|c|}{ Breeds } & \multirow[b]{2}{*}{ SEM } & \multirow[b]{2}{*}{ Normal Range 2} \\
\hline & Rambouillet & Suffolk & Dorper-cross & & \\
\hline BUN & 22.6 & 22.9 & 21.9 & 1.0 & $12-32$ \\
\hline Bilirubin & 0.1 & 0.1 & 0.1 & 0.005 & $<0.3$ \\
\hline Creatinine & 0.8 & 0.9 & 0.8 & 0.1 & $0.3-1.3$ \\
\hline AST & 82.9 & 81.2 & 86.8 & 4.4 & $51-130$ \\
\hline GGT & 52.0 & 53.3 & 60.5 & 3.2 & $34-82$ \\
\hline
\end{tabular}

${ }^{1}$ BUN indicates blood urea nitrogen; AST, serum aspartate transaminase; GGT, gamma glutamyltransferase.

${ }^{2}$ Reference range for healthy sheep as reported by the Texas Veterinary Medical Diagnostic Lab, College Station, Texas. 


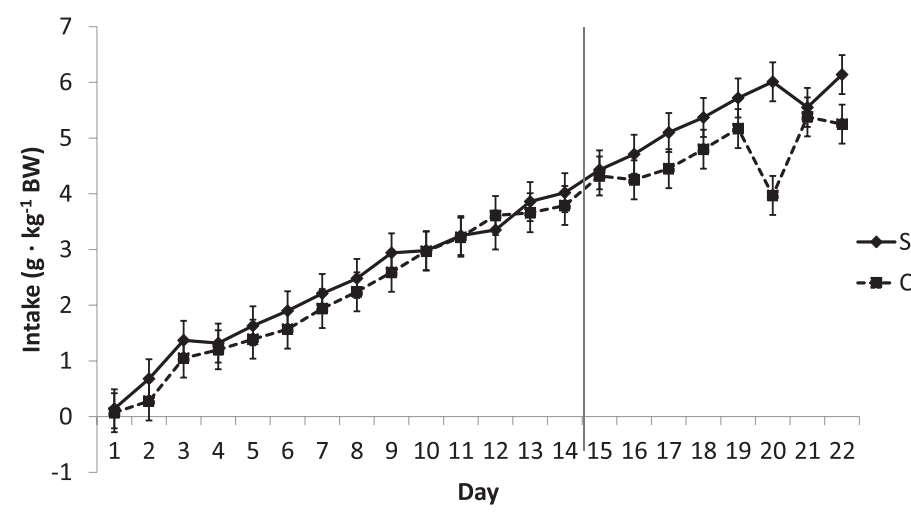

Figure 2. Intake $\left(\mathrm{g} \cdot \mathrm{kg}^{-1}\right.$ body weight $\left.[\mathrm{BW}]\right)$ of redberry juniper for lambs receiving a protein supplement $(S)$ or no supplementation $(C)$ across $22 \mathrm{~d}$ of feeding juniper in Trial 2. Intake was similar $(P>0.05)$ between treatments.

juniper when released on pasture (Dietz et al. 2010). Unfortunately, it is unknown if the results observed in pen situations with sheep will continue on pasture.

Sheep were fed juniper at weaning for this study. Both ruminant and nonruminant animals form food preferences early in life (Provenza 1995, 1996). In some cases, animals that are exposed to toxic plants early in life continue to consume poisonous plants later in life and might avoid toxicosis because of physiological adaptations allowing for detoxification of phytotoxins (Distel and Provenza 1991; Walker et al. 1992; Olson et al. 1996). The neurological, physiological, and morphological processes are susceptible to change in immature animals and can be manipulated to enhance their foraging skills and preferences (Provenza 1995). The sheep in these experiments were introduced to juniper after weaning, which is an important time in the development of feeding preferences because of the loss of maternal influences (Hinch et al. 1987). There is some evidence that digestive physiology can be altered through exposure to poisonous plants early in life to the point that ruminants can avoid aversive feedback and tissue damage from toxicosis. This observation was illustrated by Distel and Provenza (1991). Goats at 6 wk of age were fed blackbrush (Coleogyne ramosissima Torr.) daily. Blackbrush contains condensed tannins that are toxic to ruminants. Goats introduced to blackbrush early in life consumed $95 \%(P<0.01)$ more blackbrush than naïve goats, were more efficient at digesting blackbrush, and excreted more uronic acid, apparently because of an increased ability to detoxify the tannins in blackbrush.

Others have speculated that goats might be adapting to the monoterpenoids in the plant (Bisson et al. 2001; Ellis et al. 2005). Dunson et al. (2007) illustrated that goats did not adapt to juniper through changes to the rumen environment; rather, hepatic involvement seems more likely. Monoterpenoids are converted from lipophilic compounds to hydrophilic conjugated compounds by phase 1 and phase 2 detoxification enzymes in the liver before urinary excretion (Foley et al. 1995). Moderate doses of juniper oil at levels nearing exposure levels seen at maximal intake levels of free ranging goats $(0.18 \mathrm{~g}$ oil $\mathrm{kg}^{-1}$ ) resulted in mild hepatic injury in the form of lipid vacuolization. At higher dose levels $\left(0.36 \mathrm{~g}\right.$ oil $\left.\cdot \mathrm{kg}^{-1}\right)$, cellular
Table 4. Serum metabolite levels pooled across three breeds of sheep that were fed juniper for $31 \mathrm{~d}$ in Trial 1. Serum metabolite levels were similar among breeds.

\begin{tabular}{lccccc}
\hline & \multicolumn{4}{c}{ Day of collection $^{2}$} \\
\cline { 2 - 5 } Serum metabolite $^{1}$ & 1 & 18 & 25 & 31 & Normal range $^{3}$ \\
\hline BUN & $21.7 \mathrm{~b}$ & $24.9 \mathrm{a}$ & $24.4 \mathrm{a}$ & $18.8 \mathrm{c}$ & $12-32$ \\
Bilirubin & $0.13 \mathrm{a}$ & $0.13 \mathrm{a}$ & $0.12 \mathrm{~b}$ & $0.12 \mathrm{~b}$ & $<0.3$ \\
Creatinine & $0.7 \mathrm{C}$ & $0.8 \mathrm{~b}$ & $0.9 \mathrm{~b}$ & $1.0 \mathrm{a}$ & $0.3-1.3$ \\
AST & 82.0 & 80.6 & 84.2 & 88.0 & $51-130$ \\
GGT & $63.0 \mathrm{a}$ & $57.8 \mathrm{~b}$ & $51.1 \mathrm{c}$ & $49.1 \mathrm{c}$ & $34-82$ \\
\hline
\end{tabular}

${ }^{1}$ BUN indicates blood urea nitrogen; AST, serum aspartate transaminase; GGT, gamma glutamyltransferase.

${ }^{2}$ Means within the same row with different superscripts differ $(P<0.05)$.

${ }^{3}$ Reference range for healthy sheep as reported by the Texas Veterinary Medical Diagnostic Lab, College Station, Texas.

necrosis and lobular encapsulation were evident (Straka et al. 2004).

Sheep were reluctant to consume juniper on day 1 , but after $31 \mathrm{~d}$ of testing, the three treatment breeds readily consumed juniper (24\% of their diet). When goats consume over $30 \%$ of their diet on a daily basis in juniper, loss of rumen bacteria is evident (Straka et al. 2004). Sheep would probably suffer from the same adverse effects if intake exceeded $30 \%$ of the diet.

Throughout this study, sheep did not show signs of toxicosis (i.e., elevated serum metabolite levels, reduced intake). Serum metabolite levels collected differed across four periods; however, all metabolite levels remained within normal range for sheep and did not increase or decrease in a linear manner. Levels seem to vary somewhat randomly. When toxicosis occurs, creatinine, AST, and GGT levels typically all increase. Creatinine levels did increase, but AST levels remained the same, and GGT levels declined. All animals did lose weight in the first trial but not the second. Lambs probably lost weight in the first trial because they were unable to meet their nutritional requirements, especially because the amount of alfalfa was reduced below the recommended level to meet maintenance requirements.

During the first trial, juniper intake data from Period 1 illustrates that sheep will consume juniper in a pen situation even though their basal diet $(2.5 \% \mathrm{BW})$ meets or exceeds nutritional requirements (NRC 2007). When the basal diet was reduced to $2 \% \mathrm{BW}$, intake increased. Intake again increased during Period 3 when the basal diet was reduced to $1.5 \%$ BW. Thus, it seems probable that 1 ) sheep will consume juniper even when alternate forages are available, and 2) sheep will increase consumption as forage quantity declines. Indeed, goats will increase intake of juniper on pasture situations as forage availability declines (Dietz et al. 2010). Goats that were conditioned to consume juniper in the same manner increased intake, whereas naïve goats increased intake of other shrubs in the pasture.

In summary, the results of this study suggest that sheep will consume juniper and that there is no difference in the three breeds most common to west central Texas. Future research should determine if sheep will continue to consume juniper when released into the pasture after weaning. In addition, recent research with goats has suggested that supplements 
formulated with protein sources that partially escape digestion in the rumen might further improve juniper consumption (George et al. 2010). Protein supplementation did not improve juniper consumption by lambs in the second trial. It is unclear why protein supplementation apparently increased intake of juniper by goats as reported by George et al. (2010) but did not increase juniper by lambs in the current study.

\section{IMPLICATIONS}

Based on the results of this study, Rambouillet, Suffolk, and Dorper-cross sheep will increase intake of redberry juniper in a pen situation by feeding the plant at weaning. Given the similarities with goats exposed to the same feeding protocol, it seems likely that producers could hand-feed juniper to replacement ewe lambs for 14-30 d during weaning to increase the likelihood of consumption on pasture. Protein supplementation is not needed to increase juniper intake by sheep but might be necessary when sheep are foraging on pasture during dry or dormant seasons when forage quality is limited.

\section{LITERATURE CITED}

Ansley, R. J., W. E. Pinchak, and D. N. Ueckert. 1995. Changes in redberry juniper distribution in Northwest Texas. Rangelands 17:49-53.

Bisson, M. G., C. B. Scott, ANd C. A. TAYLoR, JR. 2001. Activated charcoal and experience affect intake of juniper by goats. Journal of Range Management 54:274-278.

Campbell, E. S., C. A. Taylor, JR., J. W. Walker, C. J. Lupton, D. F. Waldron, and S. Y. LANDAu. 2007. Effects of supplementation on juniper intake by goats. Rangeland Ecology \& Management 60:588-595.

Corneluss, C. E. 1989. Liver function. In: J. J. Kaneko [ed.]. Clinical biochemistry of domestic animals. New York, NY, USA: Academic Press. p. 364-397.

Dietz, T. H., C. B. Scott, E. J. Campbell, C. J. Owens, C. A. Taylor, JR., and R. Brantely. 2010. Feeding redberry juniper (Juniperus pinchottii) at weaning increases juniper consumption by goats on pasture. Rangeland Ecology \& Management 63:366-372.

Distel, R. D., and F. D. Provenza. 1991. Experience early in life affects voluntary intake of blackbrush by goats. Journal of Chemical Ecology 17:431-450.

Dunson, W. T., C. B. Scott, E. S. Campbell, C. A. Taylor, Jr., M. A. Carr, and T. R. Callaway. 2007. Chapter 64: rumen function and the ability of goats to consume redberry juniper (Juniperus pinchottii). In: K. E. Panter, T. L. Wierenga, and J. A. Pfister [EDS.]. Poisonous plants: global research and solutions. Wallingford, UK: CABI Publishing. p. 377-385.

Dye, K. L., D. N. UeCKert, and S. G. Whisenant. 1995. Redberry juniper-herbaceous understory interactions. Journal of Range Management 48:100-107.

Ellis, C. R., R. E. Jones, C. B. Scott, C. A. Taylor, JR., J. W. Walker, and D. F. Waldron. 2005. Sire influence on juniper consumption by goats. Rangeland Ecology \& Management 58:324-328.
Foley, M. J., S. McLean, and S. J. Cork. 1995. Consequences of biotransformation of plant secondary metabolites on acid-base metabolism in mammals: a final common pathway? Journal of Chemical Ecology 21:721-743.

George, C. H., C. B. Scott, T. R. Whitney, C. J. Owens, B. J. May, and R. Brantley. 2010. Supplements containing escape protein improve redberry juniper consumption by goats. Rangeland Ecology \& Management 63:655-661.

Hinch, G. N., E. Lecrivian, J. J. Lynch, and R. L. Elwin. 1987. Changes in maternal young associations with increasing age of lambs. Applied Animal Behaviour Science 17:305-318.

Johnson, P. A., A. Gerbolini, D. Ethridge, C. Britton, and D. Ueckert. 1999. Economics of redberry juniper control in the Texas rolling plains. Journal of Range Management 52:569-574.

NRC [National Research Council]. 2007. Nutrient requirements of small ruminants: sheep, goats, cervids, and New World camelids. Washington DC, USA: National Research Council. $362 \mathrm{p}$.

Olson, B. E., R. T. Wallander, V. M. Thomas, and R. W. Kott. 1996. Effect of previous experience on sheep grazing leafy spurge. Applied Animal Behaviour Science 50:161-176.

Pritz, R. K., K. L. Launchbaugh, and C. A. Taylor, JR. 1997. Effects of breed and dietery experience on juniper consumption by goats. Journal of Range Management 50:600-606.

Provenza, F. D. 1995. Postingestive feedback as an elementary determinant of food preferences and intake in ruminants. Journal of Range Management 48:2-17.

ProvenzA, F. D. 1996. Acquired aversions as the basis for varied diets of ruminants foraging on rangelands. Journal of Animal Science 74:2010-2020.

Riddle, R. R., C. A. Taylor, JR., M. M. Kothmann, and J. E. Huston. 1996. Volatile oil contents of ashe and redberry juniper and its relationship to preference by angora and Spanish goats. Journal Range Management 49:35-41.

SAS Institute Inc. 2007. JMP User's Guide. Version 7.0. Cary, NC, USA: SAS Institute Inc. $487 \mathrm{p}$

Smeins, F. E., and S. D. Fuhlendorf. 1997. Biology and ecology of ashe (blueberry) juniper. In: C. A. Taylor [ED.]. Proc. Juniper Symposium. San Angelo, TX, USA: Texas Agricultural Experiment Station. Technical Rept. 97-1. p. 33-47.

Steuter, A. A., AND C. M. BRitton. 1983. Fire-induced mortality of redberry juniper (Juniperus pinchotii Sudw.). Journal of Range Management 36:343-345.

Straka, E., C. B. Scott, C. A. Taylor, JR., and E. M. Balley. 2004. Biological control of the toxic shrub juniper. In: T. Acamovic, C. S. Stewart, and T. W. Pennycott [EDS.]. Poisonous plants and related toxins. London, UK: CABI Publishing. $p$. 436-442.

Utsumi, S. A., A. F. Cibils, R. E. Estell, and Y. F. Wang. 2006. Influence of plant material handling protocols on terpenoids profiles of one seed juniper saplings. Journal of Range Management 59:668-673.

Waldron, D. F., C. A. Taylor, Jr., J. W. Walker, E. S. Campbell, C. J. Lupton, T. D. Willingham, and S. Y. Landau. 2009. Heritability of juniper consumption in goats. Journal of Animal Science 87:491-495.

Walker, J. W., K. G. Hemenway, P. G. Hatfield, and H. A. Glimp. 1992. Training lambs to be weed eaters: studies with leafy spurge. Journal of Range Management 45:245-249.

WILcox, B. P. 2002. Shrub control and streamflow on rangelands: a process based viewpoint. Journal of Range Management 55:318-326.

Wilcox, B. P., M. K. Owens, R. W. Knight, And R. K. Lyons. 2005. Do woody plants affect streamflow on semiarid karst rangelands. Ecological Applications 15:127136.

Wink, R. L., AND H. A. WRight. 1973. Effects of fire on an ashe juniper community. Journal of Range Management 26:326-329. 